UDC 338.517

(C) 2016

M. Ibatullin, candidate of sciences (Economics)

National University of Life and Environmental Sciences of Ukraine

\title{
PORK-GRAIN PRICE RELATIONSHIP AS THE MAJOR FACTOR OF MARKET OF PORK
}

The purpose. Development of theoretical rules and practical references on optimum relationship of prices for grain and pork with the purpose of increase of production of swine breeding in agricultural factories. Methods. Dialectic method of scientific knowledge, analysis and synthesis, systemic generalization. Results. It is proved that disbalance of prices in farming industry has led to disparity of the prices and as result to disturbance of equivalence of exchange between spheres of agrarian and industrial complex. With the purpose to form parity of mutual relations it is necessary to apply methods of state regulation. Conclusions. For agricultural commodity producers it is important that clearance prices allowed gaining profit and promoted the expanded reproduction. With this purpose it is necessary to apply support prices for agricultural products, calculated on the basis of target prices and to use mortgage operations.

Key words: price, market, grain, pork, agricultural producers.

The statement of the problem. For agricultural enterprises of the economy is characterized by many structures. So, the majority of farms perform production activities like crop and animal husbandry, but mainly along with the pigs feeding at the same time engaged in the production of grain. Each entity, establishing certain proportions in size-functioning branches, comes from a combination of factors and conditions that can affect the size of the profit. In the economic system conditions for the reproduction of its individual elements may be different, however, the 
persistence of these conditions over a relatively long period may lead to qualitative changes in the structure of the economy.

Note that the majority of scholars and practitioners examine the price disparity as constraint of development of the financial condition of agricultural producers, which limits the possibilities for ensuring expanded reproduction.

In domestic practice it is widely believed that the violation of price parity for agricultural products is one of the main reasons for the decline of the industry that must be prevented measure and public policy and the consolidation of the internal capacity of agricultural producers to improve the profitability of their activities. A synthesis of the legislative framework for the regulation of development of agrarian sector of economy had been determined at the state level, the monitoring of compliance with the parity between the prices of "Inbox" material resources and agricultural products through the adoption of the draft Law of Ukraine "On parity of prices for agricultural products consumed in agriculture, industrial products and services ", but due to certain circumstances he was not adopted by the Surpreme Rada of Ukraine.

Material and methods of research. To solve the work tasks have applied the dialectical method of scientific cognition, analysis and synthesis; system synthesis. Analysis of recent researches and publications.

Research of features of formation of prices and pricing processes in the agricultural sector are constantly in view of domestic and foreign scientists, among them V. G. Andriychuk, Yu. Voskoboynik, M. Y. Demyanenko, V. A. Esipov, M. V. Zubets, M. H. Koretsky, V. L. Cornu, P. M. Makarenko, L. Y. Miller, J. F. Miller,. Th. Paskhaver, Vladimir Pensco, P. T. Sabluk, V. G. Tkachenko, N. M. Tsebenko, L. G. Shmorhun, O. G. Spikula, M. A. Špičák. However, despite significant scientific heritage, these questions always remain relevant and require further research, especially concerning the price parity between crop and livestock production. Formulation of aims of the article. The aim of the research is development of theoretical provisions and practical recommendations on optimal price ratios for grain and pork for the purpose of increasing production of pork products in agricultural enterprises. 
The main material of the study. The yield of one or another type of agricultural production is determined by the ratio of the price at which the manufacturer sold the goods, and the cost of its production and sales. Under the price is relatively quantitative expression of value of one commodity in units of other goods. Thus, a commodity producer, selecting priorities for the fattening pigs and the production of grain, focuses on the actual and expected price levels for pork and grain. That is, relatively speaking, pig-grain ratio, or coefficient, shows that the cost of a few quintals of grain equals the price of a hundredweight of pork [1, p. 17].

The cost of concentrated feed (grain, fodder) per unit of pork products and their price have a direct impact on the cost and price and, consequently, on its competitiveness. Considering primarily the cost plus method of pricing, the development of proposals for management of competitiveness of pork is necessary as priority activities to include reducing the cost of grain, its consumption per unit of production and transaction costs [2, p. 60].

The price of coarse grains is largely determined by the cost of its delivery to the place of feeding, which is important for specialized livestock complexes, working on the purchase of fodder to produce its own feed. And because of the lack of available working capital to purchase cheaper grain during the mass collection and containers for storage farms have in the following months to spend the funds in 1.5-2 times more, leading to higher end products. Creation of own raw material base through the acquisition of land into ownership or on lease for growing fodder and forage crops diverts financial resources of enterprises for the development of the core business. The best solution to this issue was the creation of integrated units, uniting producers of grain, livestock products, fodder enterprises, and the establishment of direct ties between grain producers and livestock producers on the terms of the contractual relationship. For the competitiveness of domestic pork products it is important to reduce the consumption of fodder grain for its production, to ensure regulatory feed consumption per head depending on the livestock species and poultry, their age, level of productivity, feed value, end use products, etc. Deviations 
from standard requirements for a metric leads to lower productivity, cost overruns cost of feed per unit of gain in live weight, the increase in feed costs and production costs.

The greatest effect provides the use of grain in the composition of biologically high-grade balanced mixed fodders nutrients.

The U.S. produces one-fourth of the world feed, in China - the tenth, in Canada and France 4\%. Only grain components, it is impossible to balance the feed, for example, for protein. For this purpose, it is administered in protein components.

In this regard, the ratio of the price of grain as the main feed for pigs and the price of pork products is a market indicator for the further development of the pork market. The level of this ratio involves consideration of a number of industrial and economic features of functioning of pig farming in a certain area. Calculating the level of correlation, we focused on two aspects. The first is determined by the importance of concentrated feed for the industry. On the one hand, the pig concentrate peculiar type of feeding, characterized by $80-90 \%$ share of concentrated feed in the diet. On the other hand, in the structure of the cost price of hundredweight of live weight of pork, the proportion of concentrates varies between $50-65 \%$. This, in our opinion, determines the highest primordial principle of this aspect to establish the level of the production cost.

The second phase depends on the estimated level of profitability. However, this takes a minimum level of $20 \%$, that is, one that provides selfsufficiency of pork production. Thus, for a $50 \%$ share of concentrated feed in the cost price of hundredweight of live weight of pigs pig grain ratio will be $1: 17$, and at $65 \%$ the percentage of $1: 13$. So, in order to carry out production activity, while ensuring a specified level of profitability, the price of a hundredweight of pork in the first case should be equal to the price of $17 \mathrm{~kg}$ of grain, and in the second - price $13 \mathrm{~kg}$ of grain.

Knowing the proportion of concentrates in the cost price of hundredweight of live weight of pigs and the approximate level of profitability, every agricultural enterprise can calculate its own pig-grain 
ratio. Based on average sale prices by agricultural enterprises for 2014 p., when the average selling price of hundredweight of grain was UAH 1801,4 determined by the desired level of prices of a ton of pork: the first ratio 30623,8 UAH, the second - 23418,2 USD. In fact, in 2014 the average price was at the level of UAH 18446,9, which corresponded to a ratio of $1: 10,2$ pig grain ratio (table.).

Clearly, the increase in this ratio means the price of a greater number of quintals of grain at the price of a unit of living mass of pigs, i.e. the reduction of concentrated feed and fattening, and raising the priority of pork production. At the same time, the decrease in the ratio means that the manufacturer is more profitable to sell more grain while saving the pig industry at a minimum acceptable level.

Dynamics of prices for grain crops and pigs, their numbers and weight head of sales of pigs in the agricultural enterprises of Ukraine

\begin{tabular}{|c|c|c|c|c|c|}
\hline \multirow{2}{*}{ Year } & \multirow{2}{*}{$\begin{array}{l}\text { Pig- } \\
\text { grain } \\
\text { ratio }\end{array}$} & \multicolumn{2}{|c|}{ Livestock of pigs } & \multicolumn{2}{|c|}{$\begin{array}{l}\text { The average weight of the } \\
\text { realized } \\
\text { unit }\end{array}$} \\
\hline & & Thousand units & $\begin{array}{l}\text { in \% till } \\
199 \\
7\end{array}$ & $\mathrm{~kg}$ & $\begin{array}{l}\text { in \% till } \\
1997\end{array}$ \\
\hline 1997 & $1: 10,1$ & 5536,9 & 100,0 & 67 & 100,0 \\
\hline 1998 & $1: 16,9$ & 4022,9 & 72,7 & 69 & 103,0 \\
\hline 1999 & $1: 3,3$ & 4283,8 & 77,4 & 69 & 103,0 \\
\hline 2000 & $1: 7,2$ & 4112,8 & 74,3 & 65 & 97,0 \\
\hline 2001 & $1: 16,2$ & 2414,4 & 43,6 & 80 & 119,4 \\
\hline 2002 & $1: 16,4$ & 2906,5 & 52,5 & 88 & 131,3 \\
\hline 2003 & $1: 8,0$ & 3390,8 & 61,2 & 84 & 125,4 \\
\hline 2004 & $1: 15,9$ & 2272,7 & 41,0 & 90 & 134,3 \\
\hline 2005 & $1: 24,3$ & 2098,5 & 37,9 & 95 & 141,8 \\
\hline 2006 & $1: 16,4$ & 2602,4 & 47,0 & 98 & 146,3 \\
\hline 2007 & $1: 9,1$ & 3257,4 & 58,8 & 99 & 147,8 \\
\hline 2008 & $1: 16,9$ & 2869,5 & 51,8 & 101 & 150,7 \\
\hline 2009 & $1: 17,7$ & 2730,9 & 49,3 & 108 & 161,2 \\
\hline 2010 & $1: 11,1$ & 3625,2 & 65,5 & 108 & 161,2 \\
\hline 2011 & $1: 9,9$ & 3319,2 & 59,9 & 108 & 161,2 \\
\hline 2012 & $1: 10,4$ & 3556,9 & 64,2 & 102 & 152,2 \\
\hline 2013 & $1: 12,1$ & 3878,9 & 70 & 100 & 149,3 \\
\hline 2014 & $1: 10,2$ & 3732,8 & 67,4 & 96 & 143,3 \\
\hline
\end{tabular}

Source: compiled and calculated according to the State statistics service of Ukraine. 
The data in table. 1 indicate that all years are characterized by insufficient level of correlation, among which the more favorable the ratio was in $2005-1: 24,3$, and the least favorable in $1999-1: 3$.

Consequently, the prices of agricultural products at the present stage controller function do not perform. The removal of restrictions on the content of a certain number of finishers for the unsettled price relations between grain and pork turned out to manufacturer disinterest in the results of their work.

The lack of market mechanisms on the background of the deteriorating industrial situation began to affect production parameters of $p$ since 1997. Therefore, the resolution of the level of pig-grain ratio for recording the value of incoming and outgoing resources, as one of the market instruments, will facilitate efficient production of pork and other livestock sub-sectors, where the largest share of feed, in particular grains.

Setting of level of pig-grain ratio as one of market aspects, to promote efficient pork production.

With the current situation (gross yield and grain prices, feed conversions, the cost of grain for seed and food) believe that the flow of feed to produce $1 \mathrm{~kg}$ of pork will decline marginally to $6.6 \%$. Manufacturers effectively use cornmeal. In the agricultural enterprises there is a significant variation of the indicators of feed conversion. Average daily liveweight gain of pigs in 2014 vs 2013 increased by $7 \mathrm{~g}$ and amounted to $481 \mathrm{~g}$ Agricultural enterprises of Ivano-Frankivsk region got the highest rate among the regions $-698 \mathrm{~g}$, the lowest rate in the Nikolaev area -281 G. the Cost of feed per $1 \mathrm{~kg}$ increase ranges from 3.3 to $7.1 \mathrm{~kg}$ feed. Units Meanwhile, modern technologies of keeping and feeding pigs can reduce the cost of feed for production of $1 \mathrm{~kg}$ pork $5 \mathrm{~kg}$ feed. units to 2.6, including grain - feed of

3.75. units to 1.8 , or 2 times. World practice shows that made in the last $20-$ 25 years, the progress in the pig industry by $25-30 \%$ due to selection and breeding work, and $50-60 \%$ of feeding [3, p. 117]. 
The improved conversion of the forage will reduce the cost of production of meat, with adequate reduction of sales prices for live cattle, organized sales system of the finished product, will affect consumer prices for meat of domestic production to decrease and increase their competitiveness in the domestic market [4, p. 278].

To maintain this situation it is necessary to observe three conditions: to eliminate the deficit of grain for fodder purpose, to maintain the optimum ratio of the prices of fodder grains and pigs, to prevent grey imports. To implement the first condition is necessary to regulate the volume of grain exports. The rapid increase without taking into account domestic needs will create difficulties in ensuring the concentrated feed [5, p. 167].

Compliance with the second condition, it is important for pig breeding farms. In 2005 was created the optimal ratio of cost of feed grain and the purchase price of live pigs, which provided the highest level of profitability during the period of independence of Ukraine within the limits of $14.3 \%$. In further decreased, which negatively affected the level of financial and economic activity of farms of the corporate sector - producers of pork products.

Finally, the third observance of conditions related to compliance with that analyzed the import of products of slaughter pigs. Uncontrolled imports of pork in the growth of its production creates an excess supply of product that with a small increase in purchasing power leads to lower prices for Ukrainian pork and can considerably complicate the problem of its marketing.

From the current uncertain situation in the market of pork products affected households and agricultural enterprises because of low demand for their products and the uncontrolled import of meat from abroad. This was indicated by the representatives of several large companies in growing pigs.

The meat processing companies don't buy the manufacturers ' products and purchase imported raw materials, which is two times cheaper. They also point to the situation with the shortage of meat and the need to reduce import duties. Domestic feeding refute statements about the lack of 
meat on the market. All the more reason to pay attention to the quality of the imported product. Despite the low prices of imported pork, sausages and meat products are not getting cheaper. Therefore, we can conclude that the existing pricing mechanism and the price level does not encourage agricultural producers to expand the volume of sales on the commodity pork market. On the contrary, they make feasible the increase of pork production, limiting opportunities of enterprises for increased production and better utilization of production capacity.

This has a negative impact on the formation of a civilized market of raw pork in the analyzed region, leads to loss of entrepreneurial initiatives aimed at the development of its own production, to the transformation of entrepreneurial ideas into illegal actions illegal importation of pork, the organization of processing, sausage shops and the sales network of products that operate outside the legal field. The importation of smuggled pork is done mainly through the delivery of m meat, fat, skin, and carcasses of pigs from Ukraine's neighboring States, usually from Poland, and mostly in its border provinces. It should be noted that the meat that comes into Ukraine illegally from Poland, pork is a fourth category patrimony of low-quality meat pigs. The nature of contraband of transport depends on the season: the greatest number occurs in the cold season the autumn-winter period. Meat is transported by private owners in semi - or non-adapted conditions medium - and small wholesale lots, usually without the necessary refrigeration equipment, partly because of seasonality.

Without verifying quality and compliance with sanitary requirements of the semi processed products of companies, private workshops of Poland hits the market region, causing economic and social losses for Ukrainian producers, as well as increasing the risk for health consumers.

Therefore, the existing problem of illegal imports has negative consequences for the development of the commodity market of pork of the analyzed region and to be dealt with at the legislative level. In the economic aspect of the problem can be solved by improving the competitiveness of pork production and the establishment of mutually beneficial, transparent 
star relations between producers and enterprises that will provide better market conditions for pork, increasing the efficiency of the price mechanism. The said mechanism should ensure a fair valuation of costs and income distribution between contractors of the market because, even using their monopoly of creating low procurement prices for pork, enterprises win in the short term, but in the long term, they can expect reductions in domestic raw material zones, reduction of volumes of processing of agricultural raw materials and domestic production.

The import of poor quality and therefore cheaper meat, will lead to lower prices in the domestic market. This phenomenon was observed on the market of animal products in Russia, where imported raw materials are much cheaper, which negatively affects the development of domestic enterprises for the production of pork. In addition, domestic production coming from small businesses in terms of quality does not meet applicable standards. Segmentation of the meat market is as follows: imported meat arrives in large meat-processing enterprises and the population through the retail network meets the demand for more expensive meat from domestic production. This happened only after a forced introduction by the Russian government quotas on import of meat. Regard meat with households were unstable and unreliable, so a cheaper imported meat was easily pushed out of consumer market with domestic food.

Subject to the receipt of imported meat preference market participants will receive the same (or increasing) income. Producers, conversely, have to lower the selling price. This behavior of farmers was noted by A. V. Chayanov: "Small family farms, mostly with manual labor, with limited markets have greater stability for survival at the expense of saving on the family budget (savings on fees) and tightening the belt" [6, c. 216]. A similar situation was observed, when the farm population had been cheap fodder farms of the public sector, selling prices of meat producers to intermediaries was decreased exactly by the amount of fodder agricultural enterprises. Reduction of prices on raw - meat - should affect the price of meat and sausage products. This has forced processors to manipulate their products. Sold meat and sausage products, manufactured in primitive 
workshops, with smuggling of imported raw materials, procured from the "shadow businesses" without payment of VAT, the price of which is $20 \%$ lower, but they are sold with VAT.

When addressing the question of import substitution of meat along with internal prices for grain and meat to take into account the world prices for these products, as well as the aggravation of the food problem in the world, the sharp rise in food prices, which is projected into the future.

Awareness of these trends allows to take preventive measures of customs- tariff regulation, taken into account in determining the purchase prices and production costs of grain and pork. The use of grain forage in purpose within the country during the actual conversion of concentrated feed is less profitable than its exports. The situation is changing with improved conversion of grain, reducing the cost of pork production, growth of competitiveness and solve the problem of import substitution.

The findings from this study. So, the essence of parity (equivalence) inter- industry exchange is a relative equality of conditions for expanded reproduction of all sectors of agriculture. These conditions are expressed in relative equality of profits, payment of a unit of labor of equal difficulty, the applied depreciation rates of fixed assets of the same type.

In recent years Ukraine has concentrated its efforts for entry into the world economic space requires a reconsideration of approaches to the definition of price equivalence. In particular, some researchers stress that at present the provision of equivalency interdisciplinary exchange does not return to pre-crisis price relationships. It is impossible to understand it as introducing a uniform profit rate in all sectors of agriculture. According to the law of world prices, the current understanding of equivalence is the essence of convergence of principles and mechanisms of state and world pricing, the orientation of internal price levels and ratios to world.

Thus for agricultural producers it is important that sales prices were allowed to make a profit and maintain expanded reproduction. With this purpose it is necessary to apply the guaranteed prices for agricultural products, calculated based on target price and enter the mortgage operations. That is, solve the problem of price disparity needs through the 
development of agricultural infrastructure to the point where agriculture would become equal with other industries, and perhaps the dominant industry of agribusiness.

\section{Conclusions.}

For agricultural commodity producers it is important that clearance prices allowed gaining profit and promoted the expanded reproduction. With this purpose it is necessary to apply support prices for agricultural products, calculated on the basis of target prices and to use mortgage operations.

\section{Bibliography}

1. Шуст О.А. Економічні засади виробництва та реалізації продукції свинарства в сільськогосподарських підприємствах/О.А. Шуст//Сталий розвиток економіки. - 2011. № 1 (4). - С. 276 - 280.

2. Кириленко І.Г. Проблеми українського села та їх вирішення у контексті аграрних трансформацій/І.Г. Кириленко, О.І. Павлов//Економіка АПК, 2010.

- № 7 . - C. $24-31$.

3. Кравець І.В. Динамічні зміни на ринку свинини/І.В. Кравець//Агроінком. - 2007. - № 11 - 12. - С. 11 - 15 .

4. Ковач Ю.Є. Ефективність свинарства в умовах сьогодення/Ю.Є. Ковач//Продуктивність агропромислового виробництва (економічні науки): наук.-практ. збірник Українського науково-дослідного інституту. — К.: НДІ

«Украгропромпродуктивність», 2011. — №19. - С. 55 - 57.

5. Іванюта В.Ф. Стан і проблеми виробництва продукції свинарства в Україні/В.Ф. Іванюта, Н.М. Бейдик//Агросвіт. — 2008. — № 10. - С. $25-27$.

6. Кісіль Д.Т. Невідкладні завдання у розвитку

свинарства/Д.Т. Кісіль//Сільський господар. - 2005. - № 5 - 6. - С. 8 10.

7. Крилова Л. Коли свинина стає прибутковою/Л. 
Крилова//Пропозиція. - 2008. - № 4. - С. 138 - 141.

8. Оляднічук Н.В. Основні напрями підвищення рівня інтенсифрікації свинарства/Н.В. Оляднічук//Економіка АПК. - 2008. - № 6. - С. 90 $-94$.

9. Палагута А. Шляхи підвищення ведення галузі

свинарства/А. Палагута//Тваринництво України. - 2005. —№ 10. С. $9-11$.

10. Эпштейн Д.Б. Паритет экономических отношений сельского хозяйства с другими отраслями/Д.Б. Эпштейн//Международный сельскохозяйственный журнал. - 2002. - № 2. - С. 8 - 24.

11. Сергеева И. Регулирование обменных отношений в мясном подкомплексе/И. Сергеева//АПК: экономика, управление. - 2003. № 3. - C. 59 - 65 .

12. Рибалко В.П. Свинарство національна галузь/В.П. Рибалко//Пропозиція.

- 2010. - № 1. - С. 116 - 118.

13. Ціни, витрати, прибутки агровиробництва та інфрраструктура продовольчих ринків; за ред. О.М. Шпичака. - К.: IAE УААН, 2000. — 585 c.

14. Шпичак О.М. Реалізація продукції особистими селянськими господарствами - витрати, ціни, ефективність/О.М. Шпичак, І.В. Свиноус.

- K.: IAE, 2008. $-320 \mathrm{c}$.

15. Чаянов A.B. Основные идеи и фоормы организации сельскохозяйственной кооперации/А.В. Чаянов. - М.: Наука, 1991. — $454 \mathrm{c}$. 